\title{
Makoto Tsuchiya \\ Faunal structures associated with patches of mussels on East Asian coasts
}

Received: 19 December 2000 / Revised: 3 April 2001 / Accepted: 10 December 2001 / Published online: 5 February 2002

(C) Springer-Verlag and AWI 2002

\begin{abstract}
Aggregations of mussels harbor a variety of associated animals and make it possible for diverse species to coexist at the shore. Species composition and diversity of the associated fauna are controlled by the position of mussel beds or patches, e.g. tidal level, age structure of mussels, quality of ambient water and by mussel species. When patches of mussels were surrounded by algal growth, a difference in the species composition of the associated fauna was recognized between the patches and algal mats. Mechanisms promoting coexistence are discussed. Biodeposit production by mussels may affect the environment both within the bed and the ambient waters. Reducing sediments showing low Eh values caused by the accumulation of biodeposits was observed in calm waters where the polychaete Capitella capitata, an indicator for organic enrichment, occurred both in the intertidal mussel bed and the subtidal sandy bottom communities. In a shallow subtidal sandy bottom of the Gulf of Thailand, where heavy bioturbation by the spatangoid urchin Brissus latecarinatus was occurring, small patches of the mussel Modiolus metcalfi increased species diversity and equitability in this habitat. Species composition was different between mussel patches and pure sandy bottoms.
\end{abstract}

Keywords Mussel patch · Biodeposition - Community structure - Species diversity - Environmental heterogeneity

\section{Introduction}

Mussel beds or patches harbor a variety of small animals in spaces provided by mussels and the seaweed growing on their shells. This biogenic system is a good example

Communicated by H. Asmus and R. Asmus

M. Tsuchiya (

Department of Chemistry, Biology and Marine Science,

Faculty of Science, University of the Ryukyus, Nishihara,

Okinawa 903-0213, Japan

e-mail: tsuchiya@sci.u-ryukyu.ac.jp

Tel.: +81-98-8958540, Fax: +81-98-8958540 for discussing the coexistence of many species in an ecological island (Tsuchiya and Nishihira 1985).

Community structure and the dynamics of small animals associated with mussel beds or patches are considered to be controlled by the situation of the bed; namely, age or size structure of mussels, patch size, abundance of algal growths on and around the bed, presence of gaps in the bed, and so on (Suchanek 1985; Tsuchiya and Nishihira 1985, 1986; Tsuchiya and Bellan-Santini 1989, 2000; Seed and Suchanek 1992; Tsuchiya and Retière 1992). However, processes of community organization, species interactions among associates, and relationships between the associates and organisms outside the patches have not been discussed sufficiently.

In this paper, I review previously published papers on the community of small animals associated with mussel beds or patches on the East Asian coasts, and add new data on related topics in order to characterize the community in this region with reference to surrounding environmental conditions.

\section{Materials and methods}

Earlier papers on the subject should be consulted for the methods applied. In short, mussel patches, which differed in age structure of mussels or patch size, were collected in order to study the effects on the community structure of small associated animals. Species composition of the community and environmental conditions, such as the amount of sediments accumulated and space volumes, were analyzed.

Patches of Mytilus edulis, recently identified as Mytilus edulis galloprovincialis, and surrounding algal mats, mainly composed of the brown alga Laurencia okamurai, were studied. All patches ranging from 100 to $200 \mathrm{~cm}^{2}$ were scraped off using a spatula. Associated animals were identified and counted. A similar survey was also conducted for the algal mat using a $10 \times 10 \mathrm{~cm}^{2}$ quadrat.

Mussel bed communities were studied both in the sheltered conditions of a harbor and on an exposed shore using a quadrat of $10 \times 10 \mathrm{~cm}^{2}$ in Aomori, northern Japan, and their subtidal benthic communities were also studied using a Smith-McIntyre grab. Benthic animals were sorted using a sieve of $1 \mathrm{~mm}$ mesh. Sediments accumulated in the mussel patches and those on the subtidal bottom were analyzed for size composition and measurement of Eh. 
Fig. 1 Species composition of small polychaetes associated with mussel patches of different age. $Y$ Young, $M P$ and $M C$ peripheral and central parts of intermediate age, and $O$ old. Species were listed in the order of abundance in each category except for the blank sector for rare species. $n$ Total number of individuals per $10 \times 10 \mathrm{~cm}^{2}$ in each patch

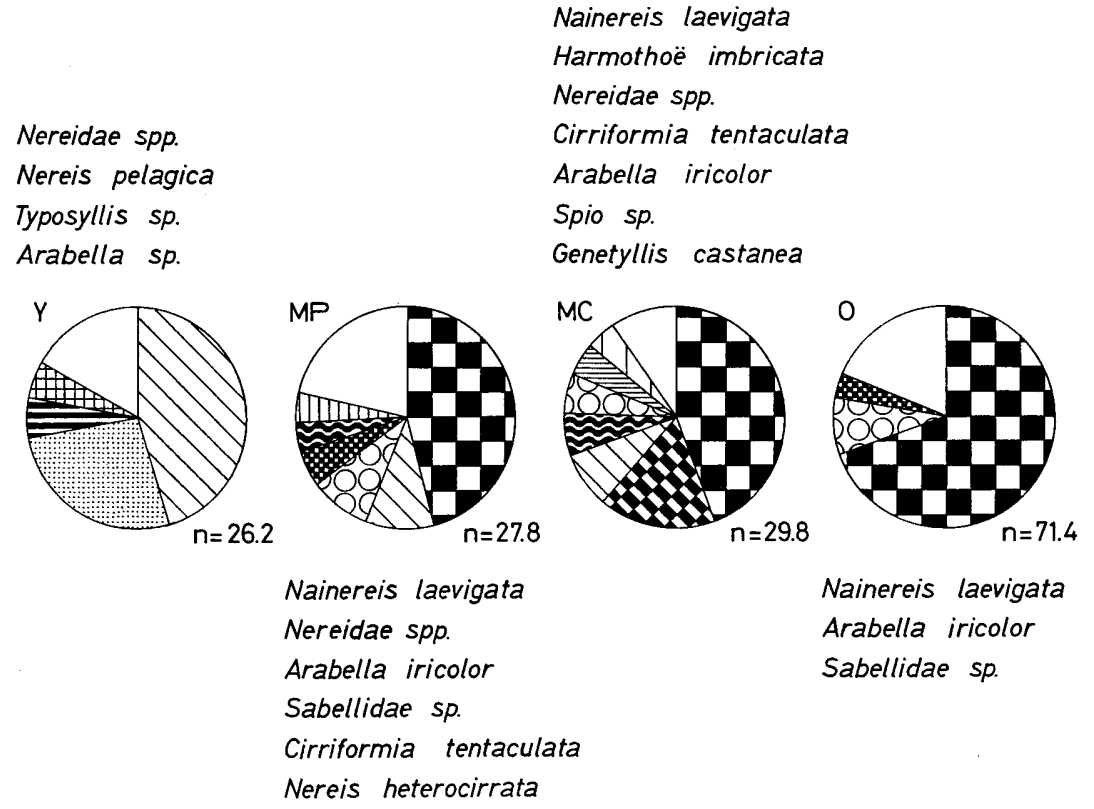

small amphipods associated with mussel patches of different ages. For Y, MP, MC and O, see Fig. 1
Hyale grandicornis

Melita sp.

Ampithoe lacertosa
Pagurus germinus
Melita sp.
Oedignathus inermis

Ampithoe lacertosa
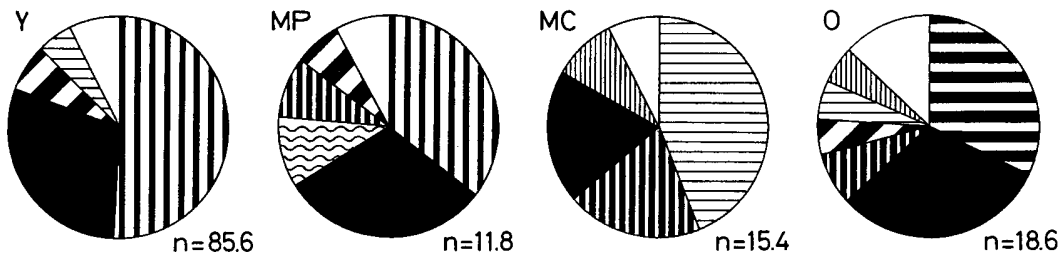

Hyale grandicornis

Melita sp.

Dynoides dentisinus

Pagurus germinus

Allorchestes plumicornis
Chthamalus challengeri

Melita sp.

Pagurus germinus

Allorchestes plumicornis

Ampithoe lacertosa

Oedignathus inermis

\section{Results}

Effect of age structure of mussels on the species composition of associated animals

The species composition of small animals associated with the mussel patches composed of Mytilus edulis of different ages was examined (Tsuchiya and Nishihira 1986). Young patches contained very small mussels $(<5 \mathrm{~mm}$ in length) and medium-sized mussels $(10-30 \mathrm{~mm})$. Size distributions of mussels in the peripheral and central parts of intermediate patches were similar, having many large mussels $(25-45 \mathrm{~mm})$ with some smaller $(<5 \mathrm{~mm})$ ones. Old patches were composed of a monolayer of large mussels (35-55 mm).

Although animals belonging to eight phyla occurred, $94 \%$ of total specimens were shared by two phyla,
Annelida and Arthropoda, of which the species composition is shown in Figs. 1 and 2. The most abundant polychaete species was the orbinid Nainereis laevigata, which was very abundant in old patches, but was absent from young ones. The arabellid Arabella iricolor was also abundant in old patches and rather large specimens (>200 mm long) were collected. On the other hand, the nereid Nereis pelagica was abundant only in young patches.

The amphipod Hyale grandicornis was concentrated in young patches and in the peripheral part of intermediate ones, but was not a dominant species in old patches. The amphipod Melita sp. was abundant in patches of all ages, but Amphithoe lacertosa was very abundant in the central part of intermediate patches. The barnacle Chthamalus challengeri attached to shells of old mussels, but was not common on younger ones. The hermit 
Fig. 3 Species composition of small molluscs associated with mussel patches of different age. For Y, MP, MC and O, see Fig. 1

\section{Collisella (Conoidacmea) heroldi \\ Temanella turrita \\ Mitrella tenuis \\ Acanthochiton rubrolineatus}
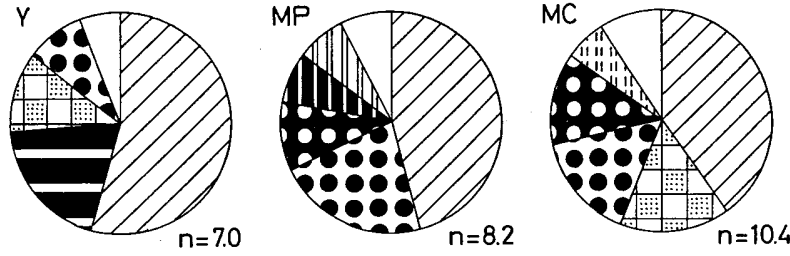

Collisella (Conoidacmea) heroldi Acanthochiton rubrolineatus Septifer (Mytilisepta) virgatus Littorina brevicula Ischnochiton comptus
Collisella (Conoidacmea) heroldi Mitrella tenuis

Acanthochiton rubrolineatus Septifer (Mytilisepta) virgatus Notoacmea schrenckii

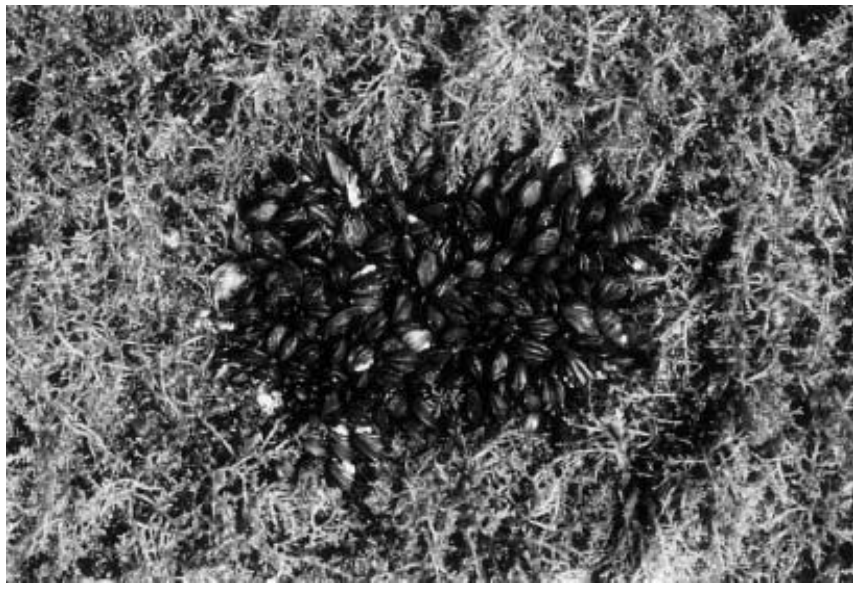

Fig. 4 A Mytilus patch surrounded by the brown alga Laurencia

crab Pagurus germinus was common in all patches except for the youngest ones.

Among molluscan species (Fig. 3), the small limpet Collisella (Conoidacmea) heroldi was found on mussel shells of all the patches. Occurrence of the small gastropod Temanella turrita was restricted to young patches and the bivalve Septifer (Mytilisepta) keenae to older ones.

Several species which were restricted to old patches were divided into three groups owing to their mode of life; (1) epizoic sessile animals such as the barnacle Chthamalus challengeri and the serpulids Hydroides ezoensis and Hydroides elegans; (2) the mussels Septifer (Mytilisepta) keenae and Modiolus modiolus difficilis; and (3) creeping fauna, the dorvilleid Dorvilela matsushimaensis and the ophiuroid Ophiophragmus japonicus. Since these species, except for Chthamalus and Septifer, were not abundant, they are not shown in Figs. 1, 2 and 3.

Species composition of associated fauna is affected by the presence of algal growths on the patches or the surrounding environment, usually the brown algae
Sargassum or Laurencia (Fig. 4). In the latter case, similar abundances in polychaete species, such as nereids and syllids, were found in both habitats $(P>0.1, t$-test $)$, while amphipods, such as Hyale grandicornis and Amphithoe lacertosa, were more abundant in the algal mats $(P<0.01, t$-test $)$. Community structure and species diversity were different from the patches without algal growths. Algal mats harbored several amphipod species, and accumulation of sand or other fine particles, which were similar to that in mussel patches (e.g. $>11 \mathrm{~g}$ in dry weight/100 $\mathrm{cm}^{2}$ ). In this case, the area also became a suitable habitat for deposit-feeding polychaete species such as Nereis pelagica or Perinereis cultrifera, showing migrations between these two habitats, mainly at low tides.

Small aggregations of Modiolus and their associates on the sandy bottom in the inner part of the Gulf of Thailand

On a shallow subtidal sandy bottom in the inner part of the Gulf of Thailand, where small patches of Modiolus metcalfi were seen and heavy bioturbation, and sediment reworking by the spatangoid urchin Brissus latecarinatus was occurring in the ambient sandy bottom, the community structure of small animals associated with the patches and that of the sandy bottom were studied with reference to the activity of the sea urchin (Fig. 5). Their sediment reworking generates the heterogeneity of the bottom surface, i.e. mounds and funnels (Tsuchiya et al. 1986, 1989; Choonhabandit and Tsuchiya 1989).

The lancelet Branchiostoma belcheri was most abundant (3.3 individuals $\left./ 100 \mathrm{~cm}^{2}\right)$ in the mounds of spatangoids, while about half as many were collected from the funnels. In the patches of Modiolus, on the other hand, its density was less than $10 \%$ of that in the ambient soft bottom.

The community associated with patches of Modiolus was characterized by a high species diversity $\left(H^{\prime}=3.05\right)$ 

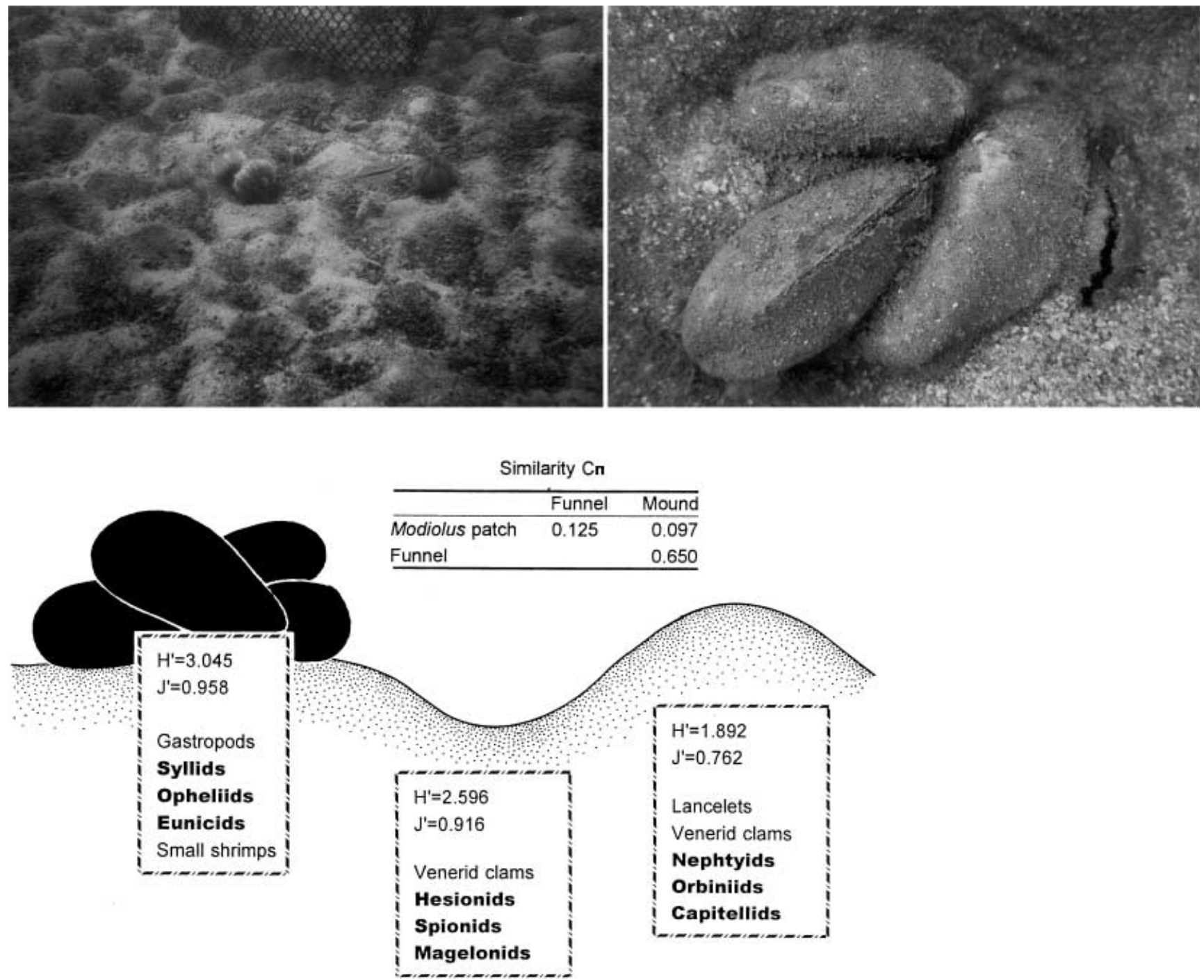

and evenness $\left(J^{\prime}=0.96\right)$. Four species of gastropods were recognized only from the microhabitat of Modiolus patches. Bivalves did not occur in the patches except for the host mussel Modiolus and there were some polychaete species belonging to the families Syllidae, Ophelidae and Eunicidae. Patches increased species diversity in this habitat, compared with the surrounding sandy bottom communities $\left(H^{\prime}=1.89-2.60\right)$.

Accumulation of fine particles in mussel patches and difference in the species composition of subtidal communities between exposed and sheltered environments

Intertidal communities of small animals associated with patches of mussels Mytilus edulis and their adjacent subtidal benthic communities were studied on an exposed shore and in calm waters of a harbor (see Tsuchiya 1979). A large amount of sediments including biodeposits was accumulated in calm conditions. Here, reducing conditions (Eh values: -153 to $-89 \mathrm{mV}$ ) were recorded. Sediments were composed of fine particles in that area.

Fig. 5 Species diversity $\left(H^{\prime}\right)$ and equitability $\left(J^{\prime}\right)$ of benthic animals found in three microhabitats, aggregation of the mussel Modiolus metcalfi, funnel and mound made by sediment reworking activity of the spatangoid urchin Brissus latecarinatus, on a sandy bottom in the inner part of the Gulf of Thailand (upper pictures). Representative benthic animal groups found in each microhabitat are also shown. $C_{\Pi}$ Kimoto's similarity index $\left(0 \leq \mathrm{C}_{\Pi} \leq 1\right)$ (Kimoto 1967)

In crevices of the exposed shore, the amount of sediment was also large, but reducing conditions were not observed.

The structure of subtidal communities and their environmental conditions, about 5-7 $\mathrm{m}$ deep and about $10 \mathrm{~m}$ apart from the intertidal mussel beds, were also different between these two environments (Fig. 6). In the sheltered conditions of the harbor, fine particles were accumulated both in intertidal mussel beds and of the subtidal bottom, causing a reducing environment there. Densities and biomass of benthic animals in the subtidal zone were different between these habitats. Indicator species for organic matter rich environment such as Capitella and 


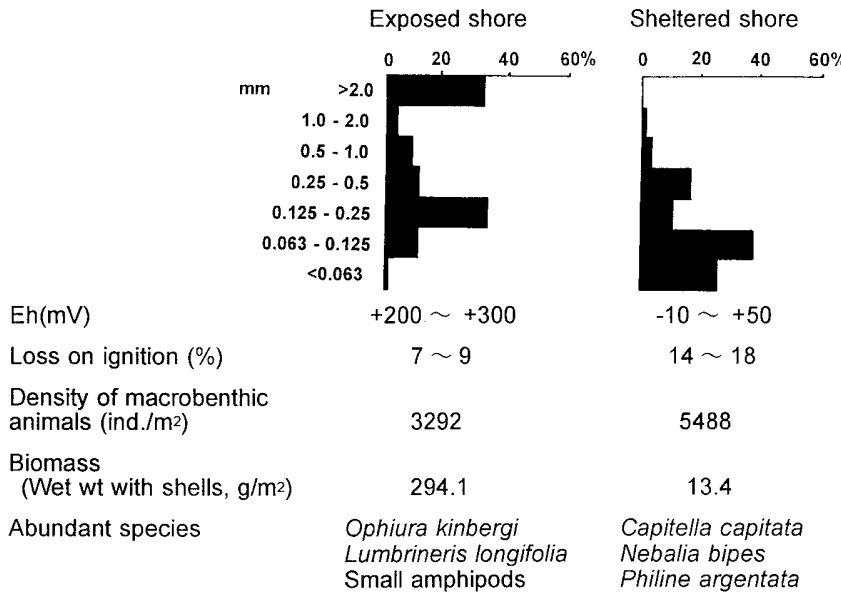

Fig. 6 Comparison of the environmental conditions and species composition of subtidal benthic communities between the exposed and sheltered shore in Aomori, northern Japan. Size distribution of sediment particles of the bottom surface is shown. Samples were collected from the bottom at about 5-7 m depth and about $10 \mathrm{~m}$ apart from the intertidal mussel beds

Nebalia were common in the harbor, but they were not collected in the exposed environment. Capitella was also common in the intertidal mussel beds developing in the harbor. Although it was merely qualitative, the amount of organic matter, which was expressed as the percentage of loss on ignition, was also larger in the calmer environment.

\section{Discussion}

The structure of the small animal population associated with mussel beds or mussel patches is modified by various factors such as age or size of mussels, tidal level, difference in mussel species, the amount of fine particles accumulated in patches and quality of ambient water.

Species composition of associates in young mussel patches differed from that found in other patches (Figs. 1, 2 and 3). Time for colonization by associated animals is shortest in the young patches. It is assumed that species found in young patches also settled on older ones. Thus, interactions between inhabitants or early settlers and new settlers might cause the death of the latter. On the other hand, biotic and abiotic environmental traits in younger patches may be unsuitable for animals inhabiting older ones because the patches may be differentially affected by wave action or predators.

Differences in environmental conditions affect the structure of both intertidal and subtidal communities. Mussels are very common on the breakwaters of harbors in Japan. Tsuchiya (1979) made a list of associated fauna of mussel beds developing on a breakwater in a sheltered and exposed rocky coasts in northern Japan. The polychaete Capitella capitata, an indicator species for organic enrichment, was abundant in the sheltered bed, where species diversity of associates was lower than in the exposed one. Hosomi (1969) observed the change in the community structure on a breakwater in Kobe, middle Japan, and reported that population sizes of the amphipod Melita koreana and some polychaete species increased with development of Mytilus beds there.

Mussel species show habitat segregation with tidal level (Hoshiai 1960, 1965; Suchanek 1979; Iwasaki 1995a, b). Iwasaki (1995a, b) reported that beds of two mussel species, Septifer viratus and Hormomya mutabilis, which were contiguous vertically, harbored different associated communities. He reported that the difference might be caused by the difference in the amount of sediments accumulated inside the beds. A similar trend was also shown in the beds of Septifer virgatus and Mytilus edulis in northern Japan (Tsuchiya 1979). The distribution of the small bivalve Lasaea undulata is restricted to the Septifer zone, but it is still unknown whether this bivalve species has a special relation with Septifer virgatus. Since biodeposit production is a function of various factors (Tsuchiya 1980), a detailed study on the relationship between the amount of biodeposits in the bed and the associated community is required.

Biomass of Mytilus aggregations has been estimated to reach a maximum of approximately $500 \mathrm{~g}$ wet weight with shell/100 $\mathrm{cm}^{2}$ (Tsuchiya 1979), showing a high productivity on a rocky shore and harboring a complex small animal community. The most important characteristic of this system must be the fact that an organism provides a habitat for other epifaunal and infaunal species, resulting in high species diversity. This was also reported for the mussel beds developing on a soft bottom (Asmus 1987). He reported that mean biomass of the Mytilus community is about 25 times higher than in ambient communities of the Wadden Sea. This large biomass is the most important factor maintaining the high species diversity, providing a heterogeneous environment for associates in aerobic conditions in the beds.

Species diversity in the Mytilus community is related to the age of Mytilus edulis and structure of space among shells. Tsuchiya and Nishihira (1986) reported that species diversity $\left(H^{\prime}\right)$ and equitability $\left(J^{\prime}\right)$ were higher in the adult beds than in younger and older ones. Suchanek (1979) also found that species richness increases with age of mussel beds. However, detailed structure within the mussel matrix has not been studied. It is speculated that large amounts of sediment accumulated inside the bed attract polychaete species and other infauna. Associated animals can be divided into several groups with regard to their environmental conditions and habitat: (1) epibenthic organisms, including barnacles, hydroids and algal species, use the shell as their habitat; (2) epiphytic fauna on algae such as amphipods; (3) mobile fauna which should be divided again into subgroups, (a) infauna living in the sediments, and (b) free-living small fauna living in the spaces between mussel shells. Species composition of each group is affected by the ambient environment and reducing conditions in accumulated fine particles mainly derived from biodeposits produced 
by mussels. This has an adverse effect on some associated animals. The export of biodeposits may affect the species composition in adjacent subtidal benthic communities.

Habitat structure and its heterogeneity provided by mussel beds needs to be discussed in detail in order to analyze their effect on the species diversity of small animals with reference to the dynamics of environmental conditions both within and around the beds and to species interactions. Habitat heterogeneity is not easy to measure quantitatively, but mussel beds provide a chance to do so and offer a variety of research topics.

Acknowledgements Thanks are due to Drs K. Reise, H. Asmus, R. Asmus and other staff members of Wattenmeerstation, Sylt, who gave me the opportunity to attend the workshop on the mussel bed community on the soft bottom in August 2000, and to Dr. J. Joslin who improved an early draft of this paper.

\section{References}

Asmus H (1987) Secondary production of an intertidal mussel bed community related to its storage and turnover compartments. Mar Ecol Prog Ser 39:251-266

Choonhabandit S, Tsuchiya M (1989) Ecological distribution of shallow macrobenthic animals on the sandy bottom of Sichang Island, the Gulf of Thailand: a preliminary report. Galaxea 7:231-239

Hoshiai T (1960) Synecological study on intertidal communities: an analysis of interrelation among sedentary organisms on artificially denuded rock surface. Bull Mar Biol Stn Asamushi Tohoku Univ 10:49-56

Hoshiai T (1965) Synecological study on intertidal communities: a synecological study on the intertidal zonation on the Asamushi coast area with reference to its reformation. Bull Mar Biol Stn Asamushi Tohoku Univ 12:93-126

Hosomi A (1969) The synecological observation on the biological succession at the surface of vertical wall of the jetty for sand arrestation of intertidal zone at the seashore of Suma, Kobe (in Japanese with English summary). Hyogo Biol 6:32-34

Iwasaki K (1995a) Factors delimiting the boundary between vertically contiguous mussel beds of Septifer virgatus (Wiegmann) and Hormonya mutabilis (Gould). Ecol Res 10:307-320
Iwasaki K (1995b) Comparison of mussel bed community between two intertidal mytillids Septifer virgatus and Hormomya mutabilis. Mar Biol 123:109-119

Kimoto S (1967) Some quantitative analysis on the Chrysomelid fauna of the Ryukyu Archipelago. Esakia 6:27-54

Seed R, Suchanek TH (1992) Population and community ecology of Mytilus. In: Gosling E (ed) The mussel Mytilus: ecology, physiology, genetics and culture, Elsevier, Amsterdam, pp 87170

Suchanek TH (1979) The Mytilus californianus community: studies on the composition, structure, organization, and dynamics of a mussel bed. PhD thesis, University of Washington, USA

Suchanek TH (1985) Mussels and their role in structuring rocky shore communities. In: Moore PG, Seed R (eds) The ecology of rocky coasts. Hodder and Stoughton, London, pp 70-96

Tsuchiya M (1979) Quantitative survey of intertidal organisms on rocky shores in Mutsu Bay, with special reference to the influence of wave action. Bull Mar Biol Stn Asamushi Tohoku Univ 16:69-86

Tsuchiya M (1980) Biodeposit production by the mussel Mytilus edulis L. on rocky shores. J Exp Mar Biol Ecol 47:203-222

Tsuchiya M, Bellan-Santini D (1989) Vertical distribution of shallow rocky shore organisms and community structure of mussel bed (Mytilus galloprovincialis) along the coast of Marseille, France. Mesogee 49:91-110

Tsuchiya M, Bellan-Santini D (2000) Change in the community structure of shallow rocky shore organisms with a comment on habitat segregation in the several species of Hyale (Amphipoda) in Marseille, France: recovery from pollution? Mesogee 58:65-75

Tsuchiya M, Nishihira M (1985) Islands of Mytilus edulis as a habitat for small intertidal animals: effect of island size on community structure. Mar Ecol Prog Ser 25:71-81

Tsuchiya M, Nishihira M (1986) Islands of Mytilus edulis as a habitat for small intertidal animals: effect of Mytilus age structure on the species composition of the associated fauna and community organization. Mar Ecol Prog Ser 31:171-178

Tsuchiya M, Retière C (1992) Zonation of intertidal organisms and community structure of small animals associated with patches of the mussel Mytilus edulis L. along the rocky coast of Dinard, Brittany, France. Bull Coll Sci Univ Ryukyus 54:47-81

Tsuchiya M, Nakasone Y, Moodee R, Manthachitra V (1986) Distribution of subtidal macrobenthic animals around the Sichang Islands, the Gulf of Thailand. Galaxea 5:75-96

Tsuchiya M, Nishihira M, Choonhabandit S, Poung-In S (1989) Environmental heterogeneity created by the spatangoid urchin Brisus latecarinatus and its effect on sandy bottom communities in the Gulf of Thailand. Galaxea 8:241-255 